\title{
Relations between serum magnesium and calcium levels and body composition and metabolic parameters in women with fibromyalgia
}

\author{
Aline Andretta ${ }^{1 *}$ (D), Maria Eliana Madalozzo Schieferdecker ${ }^{2}$, Ricardo Rasmussen Petterle ${ }^{3}$, \\ Eduardo dos Santos Paiva ${ }^{4}$ and César Luiz Boguszewski ${ }^{5}$
}

\begin{abstract}
Objective: Correlate serum magnesium (Mg) and Calcium (Ca) levels with body composition and metabolic parameters in women with fibromyalgia (FM).

Patients and methods: Cross-sectional study compared with a control group paired by age and body mass index (BMI) of adult women diagnosed with fibromyalgia. All participants went through assessment of their body composition through dual-energy X-ray absorptiometry (DXA) and had blood samples collected for dosing of Mg, $\mathrm{Ca}$, C-reactive Protein (CRP), lipidogram and glycemia. Results: 53 women with FM (average age $48.1 \pm 8.2$ years, average BMI $26.6 \pm 4.5 \mathrm{~kg} / \mathrm{m}^{2}$ ) and 50 control women (average age $47.1 \pm 9.9$ years, average BMI $25.6 \pm 3.6 \mathrm{~kg} / \mathrm{m}^{2}$ ) participated in the study. Serum levels turned out to have inverse correlation with CRP in the FM group ( $r=-0.29$, $p=0.03)$ and with BMI and glycemia in the control group $(r=0.31 ; p=0.02$ and $r=0.48 ; p=0.0004$ respectively). Serum levels of calcium correlated with triglycerides $(r=0.29 ; p=0.03)$ in the FM group and with glycemia in the control group $(r=0.64 ; p=0.0001)$.
\end{abstract}

Conclusions: In patients with FM, magnesemia turned out to have inverse correlation with CRP and calcemia had positive association with triglycerides.

Keywords: Fibromyalgia, Magnesium, Calcium, Glycemia, Lipidogram

\section{Introduction}

Fibromyalgia (FM) is a rheumatological condition characterized by diffuse, chronic musculoskeletal pain associated to various other symptoms, such as fatigue, sleep disorders, depressive episodes and cognitive and intestinal dysfunction $[1,2]$.

Generalized chronic pain has been recently associated to an increase in mortality risk and especially to death by cancer and cardiovascular conditions [3].

\footnotetext{
*Correspondence: alineandretta@hotmail.com

A cross-sectional study that evaluated the correlation between serum magnesium (Mg) and calcium (Ca) levels with the body composition and metabolic parameters in women with fibromyalgia and women without it. ${ }^{1}$ Department of Internal Medicine, Federal University of Parana (UFPR), Curitiba, PR, Brazil. Rua General Carneiro, 181, Curitiba, PR 80060-900, Brazil Full list of author information is available at the end of the article
}

In addition to chronic pain, patients with FM usually have higher body mass indexes (BMI) and are physically inactive, two risk factors that contribute to the development of metabolic syndrome. A study by Loevinger et al. (2007) found that women with fibromyalgia are 5.56 times more likely to have metabolic syndrome than healthy control subjects, given that they have higher levels of arterial blood pressure, larger waist circumference, higher glycated hemoglobin, as well as higher serum levels of triglycerides and cholesterol 4).

The longitudinal study Nord-Trøndelag Health (HUNT) identified BMI as an independent risk factor for the development of FM and concluded that being overweight has an increased FM risk [4].

Recently, the importance of dietary nutrients has been recognized in the treatment of FM and detection of 
unbalanced levels of vitamins and minerals in body fluids and tissues [5].

Several studies have shown that patients with chronic pain do not follow the recommended dietary intake levels of most vitamins and minerals [6-9].

Additionally, numerous studies have investigated the impact of magnesium $(\mathrm{Mg})$ in the quality of life of patients with pain [10]. The deficiency in $\mathrm{Mg}$ has been associated to cephalea, migraine, fibromyalgia, increase in c-reactive protein levels (CRP), osteoporosis, cardiovascular disease, changes in the metabolism of glycose and other conditions [11]. Low serum magnesium levels seem to be predictive of Metabolic Syndrome and Type2 Diabetes [12].

Magnesium frequently acts as natural antagonist of Calcium. The two cations compete in the modulation of muscular contraction, as well as in the regulation of several enzymatic reactions involved in energy metabolism, signal transduction and brain activity $[13,14]$.

Currently, little is known about the relation between chronic pain conditions, metabolic disorders and the roles of $\mathrm{Mg}$ and $\mathrm{Ca}$ in women with FM. However, studies have found associations between serum $\mathrm{Mg}$ and $\mathrm{Ca}$ levels and metabolism of lipids and cardiovascular disease risk [15-18].

This study aims at correlating serum magnesium and calcium levels with body composition and metabolic parameters in women with fibromyalgia.

\section{Materials and methods}

Observational analytical cross-sectional study approved by the Research Ethics Committee of the Hospital de Clínicas of the Federal University of Paraná (HC/UFPR) according to its approval no. 8786 dated 27 March 2012. The study analyzed women in ages between 18 to 60 years, selected at the Rheumatology Outpatient Clinic at the HC/UFPR, who had been diagnosed with FM according to criteria set forth by the American College of Rheumatology (ACR) in 1990 [1]. The reason for including only women in the study was the low prevalence of fibromyalgia among men. The control group consisted of women with the same age span who did not have FM and other associated clinical conditions.

Patients with fibromyalgia and depression or anxiety were only included if their treatment had remained unchanged for 3 months. The exclusion criteria were: use of calcium and magnesium supplements, medication change over the previous 4 weeks, use of corticosteroids or anticytokine agents, pregnancy, lactation, and a diagnosis of diabetes, decompensated endocrine diseases, infectious diseases (over the previous 4 weeks), demyelinating neurological diseases, peripheral neuropathies, inflammatory articular diseases, systemic autoimmune diseases, severe cardiovascular diseases, malignancy (over the previous year), and severe psychiatric diseases (substance abuse, schizophrenia, psychosis). Nonsteroidal anti-inflammatory agents were suspended $48 \mathrm{~h}$ before collection of blood samples, and all other medications were required to remain unchanged for at least 30 days.

After having executed an Informed Consent Agreement, all women underwent anthropometric assessment, analysis of body composition and collection of blood samples.

The anthropometric assessment was performed by means of body mass index (BMI), consisting of the relation between body weight in kilograms and body height squared in meters: $\mathrm{BMI}=$ weight $/$ height $(\mathrm{m})^{2}$. The ranges are as follows: underweight $<18.5 \mathrm{~kg} / \mathrm{m}^{2}$, eutrophic between 18.5 and $24.9 \mathrm{~kg} / \mathrm{m}^{2}$, overweight between 25 and $29.9 \mathrm{~kg} / \mathrm{m}^{2}$, and obese $>30 \mathrm{~kg} / \mathrm{m}^{2}$ [19].

The assessment of body composition was performed by means of dual-energy X-ray absorptiometry (DXA) using the Lunar Prodigy Advance DPX device at the Endocrinology and Metabolism Service of UFPR (SEMPR) with a specialized technique. Results were issued using Encore Version 12.10 software stating fat body mass (FBM) and lean body mass (LBM) in grams then converted to kilogram (kg), and FBM in percentage.

Blood samples for measuring serum magnesium $(\mathrm{Mg})$ and calcium (Ca), ultra-sensitive C-reactive protein (USCRP), total cholesterol (TC), low-density lipoproteins (LDL), high-density lipoproteins (HDL), triglycerides (TG) and glycemia were drawn in the morning after a $10-12-h$ fast. They were then placed in ice and centrifuged at $4{ }^{\circ} \mathrm{C}$. The serum was stored at $-80^{\circ} \mathrm{C}$ for later analysis at the UFPR Clinical Analysis Laboratory.

\section{Statistical analysis}

Analyses have been performed by $\mathrm{R}$ software version 3.0.2 (R Development Core Team, 2013). The ShapiroWilk test was performed to assess data normality. To test statistical differences between the two groups, the parametric Student's t-test was performed when data conformed to normality and the non-parametric Wilcoxon-Mann-Whitney test was performed for nonnormal data. To establish correlation between the results, the Pearson correlation coefficient was used for data that conformed to normality and Spearman's correlation coefficient was adopted for non-normal data. Significance level was assumed to be $95 \%(p<0.05)$.

\section{Results}

Fifty-three women with FM and 50 women without it participated in this study. The average age, BMI, and fat body mass and lean body mass percentage were equivalent in the groups (Table 1). 
Table 1 General characteristics of the participants with fibromyalgia and controls

\begin{tabular}{|c|c|c|c|c|c|}
\hline \multirow[t]{2}{*}{ Variables } & \multicolumn{2}{|c|}{ Fibromyalgia $n=53$} & \multicolumn{2}{|c|}{ Controls $n=50$} & \multirow{2}{*}{$\begin{array}{l}p- \\
\text { Value }\end{array}$} \\
\hline & Mean \pm SD & median (min-max) & Mean \pm SD & median (min-max) & \\
\hline Age (years) & $48.1 \pm 8.2$ & $49(26-60)$ & $47.1 \pm 9.9$ & $50(23-60)$ & 0.8018 \\
\hline $\mathrm{BMI}\left(\mathrm{Kg} / \mathrm{m}^{2}\right)$ & $26.6 \pm 4.5$ & $26.8(15.2-38.6)$ & $25.5 \pm 3.6$ & $24.9(19.2-32.9)$ & 0.2123 \\
\hline Lean mass (\%) & $60.4 \pm 7.5$ & $59.8(43.8-82.1)$ & $60.2 \pm 6.9$ & $58.9(48.4-77.9)$ & 0.89 \\
\hline Fat mass (\%) & $39.6 \pm 7.5$ & $40.1(18-56.2)$ & $39.8 \pm 6.9$ & $41.1(22.1-51.6)$ & 0.877 \\
\hline \multicolumn{6}{|l|}{ Laboratory tests } \\
\hline Magnesium serum (mg/dL) & $2.2 \pm 0.1$ & $2.2(1.8-2.6)$ & $2.2 \pm 0.2$ & $2.2(1.8-2.6)$ & 0.577 \\
\hline Calcium serum (mg/dL) & $9.7 \pm 0.5$ & $9.6(8.8-11.2)$ & $9.6 \pm 0.4$ & $9.7(8.8-10.3)$ & 0.3163 \\
\hline US-CRP (mg/dL) & $0.3 \pm 0.4$ & $0.2(<0.09-1.9)$ & $0.3 \pm 0.4$ & $0.1(<0.09-2.6)$ & 0.454 \\
\hline $\mathrm{TC}(\mathrm{mg} / \mathrm{dL})$ & $210.4 \pm 35.4$ & $207(140-287)$ & $203.3 \pm 30.4$ & $201.5(133-266)$ & 0.279 \\
\hline $\mathrm{LDL}(\mathrm{mg} / \mathrm{dL})$ & $138.5 \pm 30.8$ & 135 (81-209) & $130.9 \pm 27.7$ & $129(62-196)$ & 0.196 \\
\hline $\mathrm{HDL}(\mathrm{mg} / \mathrm{dL})$ & $47.1 \pm 11.1$ & $46(30-84)$ & $50.3 \pm 12.2$ & $49(28-78)$ & 0.133 \\
\hline $\mathrm{TG}(\mathrm{mg} / \mathrm{dL})$ & $123.6 \pm 67.6$ & $100(35-311)$ & $110.6 \pm 67.6$ & $96(44-427)$ & 0.283 \\
\hline Glycemia (mg/dL) & $82.9 \pm 8.9$ & $82(59-101)$ & $83.9 \pm 9.2$ & $83(60-103)$ & 0.593 \\
\hline
\end{tabular}

$B M I$ body mass index, US-CRP C- ultra-sensitive C-reactive protein, $T C$ total cholesterol, $L D L$ low-density lipoproteins, $H D L$ high-density lipoproteins, $T G$ triglycerides. Student's $t$ test for the parametric data and the Wilcoxon Mann-Whitney test were used for the non-parametric. $p<0.05$ is statistically significant

No significant differences in quantities of serum $\mathrm{Mg}$, Ca, CRP-US, TC, LDL, HDL, TG e glycemia were found in the groups (Table 1).

BMI had positive correlation with the levels of serum $\mathrm{Mg}$ in the control group $(\mathrm{r}=0.31 ; p=0.02)$. Percentages of fat body mass and lean body mass did not correlate with levels of serum $\mathrm{Mg}$ and $\mathrm{Ca}$ (Table 2).

In relation to the metabolic parameters, the level of serum $\mathrm{Mg}$ correlated negatively with CRP-US $(\mathrm{r}=-0.29$; $p=0.03$ ), and TG had positive correlation with the level of serum $\mathrm{Ca}(\mathrm{r}=0,29 ; \mathrm{p}=0,03)$ for women with $\mathrm{FM}$. In the control group, levels of serum $\mathrm{Mg}$ and $\mathrm{Ca}$ had positive correlation with glycemia $(\mathrm{r}=0.48 ; p=0.0004$ and $\mathrm{r}=0.64 ; p=0.001$, respectively) (Table 2 ).

Due to the solid correlation found between levels of serum $\mathrm{Mg}$ and $\mathrm{Ca}$ and glycemia, the FM group and the control group were divided in $\mathrm{BMI}<25 \mathrm{Kg} / \mathrm{m}^{2}$ and $\mathrm{BMI} \geq 25 \mathrm{Kg} / \mathrm{m}^{2}$. With such division, it was possible to detect that the correlation between glycemia and calcemia was maintained in the groups with $\mathrm{BMI}<25 \mathrm{Kg} / \mathrm{m}^{2}$ $(\mathrm{r}=0.64 ; p=0.0005)$ and with $\mathrm{BMI} \geq 25 \mathrm{Kg} / \mathrm{m}^{2}(\mathrm{r}=0.63$; $\mathrm{p}=0.001)$. Magnesemia correlated with glycemia only in the control group with $\mathrm{BMI} \geq 25 \mathrm{Kg} / \mathrm{m}^{2}(\mathrm{r}=0.59 ; p=$ $0.003)$. Women with FM did not have such correlations (Table 3).

\section{Discussion}

The reduction of levels of serum micronutrients in patients with FM is a rather controversial subject. Although some studies have shown lower intracellular and serum contents of $\mathrm{Mg}$ and higher Ca levels in patients with FM [20-23], our study did not find such difference in levels of serum $\mathrm{Mg}$ and $\mathrm{Ca}$ in the FM group or in the control group. Nevertheless, it is fundamental to analyze such fact more deeply, given that studies have employed different methodologies for measuring minerals and produced varying serum, erythrocyte, leucocyte, urinary, muscular and hair levels.

Numerous studies have reported that patients with fibromyalgia have high body mass indexes and are more likely to develop metabolic syndrome [3, 24, 25]. However, in this research, the study group was equivalent to the control group in terms of BMI, therefore, it was not possible to notice differences in connection with body composition and metabolic parameter between the groups.

A relevant fact found in our study, though, was the inverse correlation between levels of serum $\mathrm{Mg}$ and CRPUS in the FM group. Several current evidences support the role of magnesium in pain reduction by blocking central sensitization through its effect on N-methyl-d-aspartate receptors [26]. Other findings have shown the important role that $\mathrm{Mg}$ plays in the physiopathology of inflammation. Lower blood concentrations of $\mathrm{Mg}$ influence inflammatory response due to an increase in proinflammatory cytokines. A meta-analysis published by Simental-Mendia et al. (2017) concluded that the supplementation of $\mathrm{Mg}$ lowers CRP levels and, consequently, has a major adjuvant role in the treatment of low-degree chronic systemic inflammation. Such mechanisms still require further understanding but may be related to the action of $\mathrm{Mg}$ as a natural antagonist of $\mathrm{Ca}$ given that higher levels of intracellular $\mathrm{Ca}$ and the activation of processes that contribute to inflammation take place while Mg is deficient [27-30].

Another relevant fact found in the FM group is the correlation in triglycerides levels with levels of serum 
Table 2 Relationship between serum magnesium and calcium levels with the variables: body composition and metabolic parameters

\begin{tabular}{|c|c|c|c|c|}
\hline \multirow[t]{2}{*}{ Variables } & \multicolumn{2}{|c|}{ Magnesium serum } & \multicolumn{2}{|c|}{ Calcium serum } \\
\hline & $\overline{F M}$ & CT & $\overline{F M}$ & $C T$ \\
\hline \multicolumn{5}{|l|}{$\overline{\mathrm{BMI}}$} \\
\hline r & -0.001 & 0.31 & 0.27 & 0.18 \\
\hline$p$ & 0.99 & $0.02 *$ & 0.05 & 0.2 \\
\hline \multicolumn{5}{|c|}{ Lean mass } \\
\hline r & -0.05 & -0.26 & -0.18 & -0.22 \\
\hline$p$ & 0.71 & 0.06 & 0.18 & 0.12 \\
\hline \multicolumn{5}{|l|}{ Fat mass } \\
\hline r & 0.05 & 0.26 & 0.18 & 0.22 \\
\hline$p$ & 0.72 & 0.06 & 0.18 & 0.12 \\
\hline \multicolumn{5}{|l|}{ US-CRP } \\
\hline r & -0.29 & -0.006 & 0.21 & 0.2 \\
\hline$p$ & $0.03^{*}$ & 0.96 & 0.11 & 0.17 \\
\hline \multicolumn{5}{|l|}{$\mathrm{TC}$} \\
\hline r & 0.182 & 0.08 & 0.24 & 0.18 \\
\hline$p$ & 0.19 & 0.56 & 0.08 & 0.21 \\
\hline \multicolumn{5}{|l|}{ LDL } \\
\hline r & 0.2 & 0.01 & 0.17 & 0.57 \\
\hline$p$ & 0.15 & 0.92 & 0.21 & 0.69 \\
\hline \multicolumn{5}{|l|}{$\mathrm{HDL}$} \\
\hline r & 0.03 & -0.12 & -0.03 & 0.03 \\
\hline $\mathrm{p}$ & 0.83 & 0.39 & 0.79 & 0.79 \\
\hline \multicolumn{5}{|l|}{ TG } \\
\hline r & 0.08 & 0.26 & 0.29 & 0.25 \\
\hline$p$ & 0.53 & 0.07 & $0.03^{*}$ & 0.08 \\
\hline \multicolumn{5}{|l|}{ Glycemia } \\
\hline r & -0.01 & 0.48 & 0.24 & 0.64 \\
\hline$p$ & 0.93 & $0.0004^{*}$ & 0.08 & $0.001^{*}$ \\
\hline
\end{tabular}

FM fibromyalgia group, CT control group, BMI body mass index, US-CRP Cultra-sensitive C-reactive protein, $T C$ total cholesterol, $L D L$ low-density lipoproteins, $H D L$ high-density lipoproteins, $T G$ triglycerides. r: correlation coefficient. ${ }^{*} P<0.05$ is statistically significant
Calcium. The relation between metabolic parameters with levels of serum $\mathrm{Mg}$ and $\mathrm{Ca}$ in persons with $\mathrm{FM}$ has not been described by research to date. Nevertheless, numerous studies with adult subjects have correlated an increase in calcemia with increased total cholesterol [18] and a progressive increase in Metabolic Syndrome [16, 17].

Despite the fact that Mg levels did not produce a relation with the lipid profile in this research study, lower $\mathrm{Mg}$ concentrations appear to be associated to a reduction in HDL and increase in LDL and TG levels [15].

In both groups in our study (FM and control), glycemia has remained fairly normal. However, it is important to notice that levels of serum $\mathrm{Mg}$ and $\mathrm{Ca}$ correlated strongly with glycemia in the control group, and such correlation did not exist in the FM group. After separating the groups in lower than- and higher than $25 \mathrm{~kg} / \mathrm{m}^{2}$, the correlation between calcemia and glycemia continued to exist in both subgroups of the control group, and the correlation between glycemia and Mg levels only continued to exist in the control subgroup with $\mathrm{BMI} \geq$ to $25 \mathrm{~kg} / \mathrm{m}^{2}$.

Apparently, there is something in the physiopathology of fibromyalgia that makes patients have different responses from the control group. A study by Malatji et al. (2017) detected that patients with FM have an abnormal metabolic state [31].

Although in this study magnesemia has correlated positively with glycemia, other studies have already shown that lower levels of serum $\mathrm{Mg}$ serum and higher levels of serum $\mathrm{Ca}$ must be considered as risk factors for cardiovascular diseases, given they correlate with hypertension, diabetes and atherosclerosis [12, 32].

Several research studies have found direct association between calcemia and diabetes risk [16, 33, 34]. Their findings have shown the association of calcemia to glycemia, fasting insulin, resistance to insulin, and inverse correlation with the function of $\beta$-cells, thus suggesting that alterations in homeostasis of serum calcium are substantially correlated to abnormalities in the metabolism of glycose [35]. Therefore, higher levels of serum calcium may be interpreted as an independent risk factor for the development of diabetes [36].

Table 3 Correlation between glycemia and serum magnesium and calcium levels in the groups divided by body mass index (BMI)

\begin{tabular}{|c|c|c|c|c|c|c|c|c|}
\hline \multirow[b]{3}{*}{ Glycemia } & \multicolumn{4}{|l|}{ Grupo FM } & \multicolumn{4}{|c|}{ Grupo Controle } \\
\hline & \multicolumn{2}{|c|}{ Magnesium serum } & \multicolumn{2}{|l|}{ Calcium serum } & \multicolumn{2}{|c|}{ Magnesium serum } & \multicolumn{2}{|l|}{ Calcium serum } \\
\hline & $\begin{array}{l}\mathrm{BMl}<25(n= \\
24)\end{array}$ & $\begin{array}{l}\mathrm{BMI} \geq 25(n= \\
29)\end{array}$ & $\begin{array}{l}\mathrm{BMl}<25(\mathrm{n}= \\
24)\end{array}$ & $\begin{array}{l}\mathrm{BMI} \geq 25(\mathrm{n}= \\
29)\end{array}$ & $\begin{array}{l}\mathrm{BMl}<25(n= \\
25)\end{array}$ & $\begin{array}{l}\text { BMI } \geq 25(n= \\
25)\end{array}$ & $\begin{array}{l}\mathrm{BMl}<25(\mathrm{n}= \\
25)\end{array}$ & $\begin{array}{l}\mathrm{BMI} \geq 25(\mathrm{n}= \\
25)\end{array}$ \\
\hline r & 0.16 & -0.31 & 0.34 & -0.13 & 0.12 & 0.59 & 0.64 & 0.63 \\
\hline$p$ & 0.44 & 0.09 & 0.1 & 0.47 & 0.55 & $0.003^{*}$ & $0.0005^{*}$ & $0.001 *$ \\
\hline
\end{tabular}

${ }^{*} P<0.05$ is statistically significant 
In another study, an increase in calcemia related to all components of the Metabolic Syndrome (MS), except HDL cholesterol. The high serum calcium levels found in these persons may result from greater intestinal absorption, increased bone reabsorption, renal absorption, or a combination of said factors [17].

In spite serum levels correlating to the risk of developing diabetes, magnesium levels are associated to improved glycose metabolism. Studies have shown a relation between supplementation of magnesium and improvement in diabetes [37]. Others have shown favorable results with supplementation of magnesium to improve sensitivity to insulin $[38,39]$ and to improve the capacities of $\beta$-cells, thus compensating the variations in sensitivity to insulin [40]. Another study has shown that supplementation of $\mathrm{Mg}$ reduced cardiovascular risk globally by reducing levels of total cholesterol, LDL and TG and increasing HDL levels [41].

The present study has limitations related to serum mineral dosage, which does not seem to be a good predictor of intracellular reserves. In addition, serum $\mathrm{Ca}$ values were not corrected by albumin, and it was not possible to measure complementary tests such as ionic Ca, Vitamin D, PTH (parathyroid hormone), and the menopausal status of the subjects, which would help to better analyze the metabolism of these minerals.

Finally, it is noteworthy that this was a cross-sectional study, which has a number of limitations inherent to its methodology. Further studies are proposed that explain in detail the mechanisms that influence these results, and whether there is anything in the pathophysiology of fibromyalgia that causes patients to have different responses from the control group.

\section{Conclusion}

Women with FM have shown inverse relation between levels of serum magnesium and CRP, and positive relation between calcemia and triglyceride levels. These findings suggest that magnesium and calcium may have a relevant role in metabolic disorders and inflammations in women with fibromyalgia. New research studies must be developed in order to better unveil the mechanisms of said minerals in the physiopathology of fibromyalgia and their relation with metabolic disorders.

\footnotetext{
Acknowledgements

The authors would like to thank the research group: Márcia Maria Marques Teles Lobo, Renata Costa de Miranda, Emmanuelle Dias Batista and Jéssica Nehring, who contributed to this work. Would like to thank also CAPES, the Nutrition Department, the Rheumatology Department and the Endocrine Division (SEMPR), Department of Internal Medicine, Federal University of Parana (UFPR), Curitiba, PR, Brazil, that made this research possible.
}

\section{Authors' contributions}

All authors participated sufficiently in the work. They were present during research, evaluation and data collection, as well as in the elaboration of statistical analyzes and in the intellectual contribution related to research and references. All authors assume public responsibility for the content of the article. If requested, authors will provide the data required for review by publishers. All authors read and approved the final manuscript.

\section{Funding}

Not applicable.

Availability of data and materials

If requested, authors will provide the data required for review by publishers.

\section{Ethics approval and consent to participate}

The Human Research Ethics Committee of Hospital de Clínicas, Federal University of Parana (CEP-HC/UFPR), manifests itself by the approval of Research Project number 8786 on 27.03.2012, CAAE: 00979612.9.0000.0096. All patients who agreed to participate received and signed an informed consent.

\section{Consent for publication}

The authors, declare that this manuscript is original, has not been published before and is not submitted for any other publication.

The authors confirm that the article was read and approved by all authors and that all authors participated sufficiently in the work, also assuming public responsibility for the content of the article.

\section{Competing interests}

The authors declare that they have no competing interests.

\section{Author details}

${ }^{1}$ Department of Internal Medicine, Federal University of Parana (UFPR), Curitiba, PR, Brazil. Rua General Carneiro, 181, Curitiba, PR 80060-900, Brazil. ${ }^{2}$ Department of Nutrition, Federal University of Parana (UFPR), Curitiba, PR, Brazil. ${ }^{3}$ Statistical Federal University of Parana (UFPR), Curitiba, PR, Brazil. ${ }^{4}$ Department of Internal Medicine, Federal University of Parana (UFPR), Curitiba, PR, Brazil. ${ }^{5}$ Endocrine Division (SEMPR), Department of Internal Medicine, Federal University of Parana (UFPR), Curitiba, PR, Brazil.

Received: 24 May 2019 Accepted: 17 February 2020

Published online: 14 March 2020

\section{References}

1. Wolfe F, Smythe H, Yunus M, Bennett R, Bombardier C, Godenberg D, et al. The American College of Rheumatology 1990 criteria for the classification of fibromyalgia. Report of the multicenter criteria committee. Arthritis Rheum. 1990:33:160-72.

2. Clauw DJ. Fibromyalgia: an overview. Am J Med. 2009;122(12):S3-S13.

3. Farstad, I. Association of chronic pain and fibromyalgia with cardiovascular risk factors and metabolic syndrome: the Norwegian HUNT study. Digitala Vetenckapliga Arkibet, p.35, 2011.

4. MORK PJ, VASSELJEN O, NILSEN TIL. Association between physical exercise, body mass index, and risk of fibromyalgia: Iongitudinal data from the Norwegian Nord-Trøndelag health study. Arthritis Care Res. 2010;62(5):611-7.

5. Bjørklunda G, Dadar M, Chirumbolo S, Aasethd J. Fibromyalgia and nutrition: therapeutic possibilities? Biomed Pharmacother. 2018;103:531-8.

6. Sendur OF, Tastaban E, Turan Y, UIman C. The relationship between serum trace element levels and clinical parameters in patients with fibromyalgia. Rheumatol Int. 2008;28:1117-21.

7. Kim Y-S, Kim K-M, Lee D-J, Kim B-T, Park S-B, et al. Women with fibromyalgia have lower levels of calcium, magnesium, Iron and manganese in hair mineral analysis. J Korean Med Sci. 2011;26(10):1253-7.

8. Meleger AL, Froude CK, Walker J. Nutrition and eating behavior in patients with chronic pain receiving long-term opioid therapy. PM R. 2014;6:7-12.

9. Batista ED, Andretta A, Miranda RC, Nehring J, Paiva ES, Schieferdecker MEM Food intake assessment and quality of life in women with fibromyalgia. Rev Bras Reumatol. 2016;56(2):105-10.

10. Pickering G, Morel V, Simen E, Cardot JM, Moustafa F, et al. Oral magnesium treatment in patients with neuropathic pain: a randomized clinical trial. Magnes Res. 2011;24(2):28-35.

11. Rosanoff A, Weaver CM, Rude RK. Suboptimal magnesium status in the United States: are the health consequences underestimated? Nutr Rev. 2012;70(3):153-64 
12. Backman L, Haglin L, Tornkvist B. A structural equation model for assessment of links between changes in serum triglycerides, urate, and glucose and changes in sérum Calcium, magnesium and phosphate in Type 2 diabetes and non-diabetes metabolismo. Cardiovasc Diabetol. 2011;10:116.

13. Vannucchi, H.; Monteiro, T.H. Funções Plenamente Reconhecidas de Nutrientes - Magnésio. Brasil International Life Sciences Institute do Brasil (ILSI Brasil), v.16, p.1-19, 2010

14. Bazzichi L, Giannaccini G, Betti L, Fabbrini L, Schmid L, et al. ATP, calcium and magnesium levels in platelets of patients with primary fibromyalgia. Clin Biochem. 2008:41:1084-90.

15. Barbagallo M, Dominguez $L$, Galioto $A$, et al. Role of magnesium in insulin action, diabetes and cardio-metabolic syndrome X. Mol Asp Med. 2003; 24(1-3):39-52.

16. Kim MK, Kim G, Jang EH, et al. Altered calcium homeostasis is correlated with the presence of metabolic syndrome and diabetes in middle-aged and elderly Korean subjects: the Chungju metabolic disease cohort study. (CMC study). Atherosclerosis. 2010;212:674-81.

17. Saltevo J, Niskanen L, Kautiainen H, Teittinen J, Oksa H, Korpi-Hyövälti E, Sundvall J, Männistö S, Peltonen M, Mäntyselkä P, Vanhala M. Serum calcium level is associated with metabolic syndrome in the general population: FIN-D2D study. Eur J Endocrinol. 2011;165(3):429-34.

18. Becerra-Tomás N, Estruch R, Bulló M, Casas R, Díaz-López A, Basora J, et al. Increased serum calcium levels and risk of type 2 diabetes in individuals at high cardiovascular risk. Diabetes Care. 2014;37:3084-91.

19. Who - world health organization. Global data base on body mass index The international classification of adult underweight, overweight and obesity according to bmi. 2004. Disponível em http://apps.who.int/bmi/ index.jsp?introPage=intro_3.html.

20. Abraham GE, Flechas JD. Management of fibromyalgia: rationale for the use of magnesium and malic acid. J Nutr Med. 1992;3(1):49.

21. Bagis $S$, Karabiber M, As I, Tamer L, Erdogan C, Atalay A. Is magnesium citrate treatment effective on pain, clinical parameters and functional status in patients with fibromyalgia? Rheumatol Int. 2013;33:167-72.

22. KASIM, A.A. Calcium, Magnesium and Phosphorous Levels in Serum of Iraqi. Women with Fibromyalgia. Iraqi J Pharm Sci, v.20, n.2, 2011

23. Joustra ML, Minovic I, Janssens KAM, Bakker SJL, Rosmalen JGM. Vitamin and mineral status in chronic fatigue syndrome and fibromyalgia syndrome: A systematic review and meta-analysis. PLoS ONE. 2017;12(4):e0176631.

24. Loevinger, B.L.; Muller, D.; Alonso, C.; Coe, C.L. Metabolic syndrome in women with chronic pain. Metabolism. v56, p.87-93, 2007.

25. Shaker, R.H.M.; Soliman, A.F.; Elbrashy, A.E.W.S.; Fouda, A.I.; Attia, S.M.. Women with Fibromyalgia: Association of Body Mass Index with Socioeconomic Status, Disease Severity, Functional Disability and Quality of Life. The Egyptian Journal of Community Medicine, v.35, n.3, 2017.

26. Hyo-Seok NA, Jung-Hee RYU, and Sang-Hwan DO. The role of magnesium in pain. Adelaide (AU): University of Adelaide Press; 2011. https://www.ncbi. nlm.nih.gov/books/NBK507245/.

27. Simental-Mendia LE, Sahebkar A, Rodriguez-Moran M, Zambrano-Galva G, Guerrero-Romero F. Effect of magnesium supplementation on plasma Creactive protein concentrations: A systematic review and meta-analysis of randomized controlled trials. Curr Pharm Des. 2017;23(31):4678-86.

28. King DE. Inflammation and elevation of C-reactive protein: does magnesium play a key role? Magnes Res. 2009;22(2):57-9.

29. King DE, Mainous AG, Geesey M, Egan BM, Rehman S. Magnesium supplement intake and C-reactive protein levels in adults. Nutr Res. 2006;26: 193-6.

30. Crosby V, Elin RJ, Twycross R, Mihalyo M, Wilcock A. Therapeutic reviews: magnesium. J Pain Symptom Manag. 2013:45(1):137-44.

31. Malatji BG, Meyer $H$, Mason S, Engelke UFH, Wevers RA, Mari van reenen MV, Reinecke CJ. A diagnostic biomarker profile for fibromyalgia syndrome based on an NMR metabolomics study of selected patients and controls. BMC Neurol. 2017;17(1):88.

32. Cunha, A.R., Umbelino, B., Correia, M.L., Neves, M.F.. Magnesium and vascular changes in hypertension. Int J Hypertens, 2012.

33. Jorde R, Schirmer H, Njølstad I, et al. Serum calcium and the calciumsensing receptor polymorphism rs17251221 in relation to coronary heart disease, type 2 diabetes, cancer and mortality: the Tromsø study. Eur J Epidemiol. 2013;28:569-78.
34. Lorenzo C, Hanley AJ, Rewers MJ, HAFFNER SM. Calcium and phosphate concentrations and future development of type 2 diabetes: the insulin resistance atherosclerosis study. Diabetologia. 2014;57:1366-74.

35. Sun G, Vasdev S, Martin GR, Gadag V, Zhang H. Altered calcium homeostasis is correlated with abnormalities of fasting serum glucose, insulin resistance, and cell function in the Newfoundland population. Diabetes. 2005;54:3336-9.

36. Song $\mathrm{CH}$, Choi WS, Oh HJ, Kim KS. Associations of serum minerals with body mass index in adult women. Eur J Clin Nutr. 2007:61:682-5.

37. Guerrero-Romero F, Rodríguez-Morán M. The effect of lowering blood pressure by magnesium supplementation in diabetic hypertensive adults with low serum magnesium levels: a randomized, double-blind, placebocontrolled clinical trial. J Hum Hypertens. 2009;23(4):245-51.

38. Guerrero-Romero F, Tamez-Perez HE, González-González G, Salinas-Martínez AM, Montes-Villarreal J, Treviño-Ortiz JH, Rodríguez-Morán M. Oral magnesium supplementation improves insulin sensitivity in non-diabetic subjects with insulin resistance: a double-blind placebo-controlled randomized trial. Diab Metab. 2004;30(3):253-8.

39. Lee S, Park HK, Son SP, Lee CW, Kim IJ, Kim HJ. Effects of oral magnesium supplementation on insulin sensitivity and blood pressure in normomagnesemic nondiabetic overweight Korean adults. Nutr Metab Cardiovasc Dis. 2009:19(11):781-8.

40. Guerrero-Romero F, Rodríguez-Morán M. Magnesium improves the beta-cell function to compensate variation of insulin sensitivity: double-blind, randomized clinical trial. Eur J Clin Investig. 2011;41(4):405-10.

41. Hadjistavri LS, Sarafidis PA, Georgianos PI, Tziolas IM, Aroditis CP, et al. Beneficial effects of oral magnesium supplementation on insulin sensitivity and serum lipid profile. Med Sci Monit. 2010;16(6):CR307-12.

\section{Publisher's Note}

Springer Nature remains neutral with regard to jurisdictional claims in published maps and institutional affiliations.

Ready to submit your research? Choose BMC and benefit from:

- fast, convenient online submission

- thorough peer review by experienced researchers in your field

- rapid publication on acceptance

- support for research data, including large and complex data types

- gold Open Access which fosters wider collaboration and increased citations

- maximum visibility for your research: over $100 \mathrm{M}$ website views per year

At BMC, research is always in progress.

Learn more biomedcentral.com/submissions 